\title{
Herbal Medicines for Livestock Health Management Used By Jende Kuruba Community in Athani Taluka of Belgaum District
}

\author{
S. N. Emmi \\ Assistant Professor, Department of Botany, K.L.E. Society’s S.S.M.S College Athani-591 304
}

\begin{abstract}
Ayurvedic science gains its own significance since ancient days. Hats off to Charaka, the father of medicine and Sushruta, the father of surgery, for introducing the life saving techniques. Herbal medicine cures so many diseases without any side effects. Herbal medicine, the gift of nature is very valuable than the man made allopathic medicine in live stock health management. Hence, the people of tribal communities who are dependent on animals and their products are physically better than the modern man and the life expectancy is also high in them.
\end{abstract}

Keywords: Livestock, Ethnoveterinary, Vaidyas, Antiseptic, Germplasm

\section{Introduction}

Present investigation is based on most of the livestock for which farmers utilize traditional veterinary practices to solve animal health problems. The holistic interdisciplinary study of local knowledge and its associated skills, practices, beliefs, is pertaining to the animal health care. Livestock owners, local medicine men or vaidyas have good knowledge of ethno botany due to the fact that most of the materia medica used in ethno veterinary medicine is from plants. Thus ethno botanical knowledge of local people has formed the foundation for screening of plant material as potential source of medical drugs.

A field manual of traditional veterinary treatment of 06 diseases in farm animals namely foot \& mouth disease, fever, diarrhea, fractures, wounds and nose bleeding is compiled, which offers a range of traditional remedies. 35\% of these diseases can be treated using traditional veterinary practices. While remaining percentage are dealt by the complementary use of ethnoveterinary medicines. Some herbs have multiple medicinal uses; others are effective as mixtures. Different herbal treatments are often cited for same disease, with varying dosages and methods of administration. Animal disease, plant used, its common name, scientific name, family \& method of application are registered in field manual. Traditional ethanoveterinary practices can generate useful information needed to develop livestock healing practices and methods that are suited to the local environment so that it contributes to biodiversity conservation. The questionnaires covered above cited livestock ailments that had been treated by traditional means and medicinal materials used $\&$ their preparation. Validation of these ethnoveterinary practices for their quality, efficacy and standardization of doses and screening for active substances may lead to the discovery of some new, safer and cost effective medicines. The awareness of medicinal importance of such plants will encourage eco-restoration of selected plant species.

\section{Study Site: Athani taluka}

Main occupation of people in Athani taluka is agriculture. Their economic income is also based on breeding and selling cattle \& selling dairy linked products like milk, curd etc. The climate is hot with average rainfall of $158 \mathrm{~mm} / \mathrm{yr}$. Frequently found plants are Azadirachta indica, Acacia arabica, Cassia fistula, Cacti, Ocimum basilicum, Tridex, Asparagus, Ricinus communis, Ipomoea indica, Bougainvillea, Solanum, Amaranthus hybridus, Lantana, Vitex negundo, Mimosa pudica etc.

\section{Methodology}

Field survey was carried out during the year 2013-14, by performing questionnaires with expert local medicine men or vaidyas, farmers, herbalists who are well known for their traditional ethno veterinary practice in more than 10 villages The informants are between 50-70 age groups. Conversation with specialists \& inhabitants were based on common objective to increase knowledge regarding natural traditional remedies of healing animals, develop educational materials of local interest as suggested in guidelines of International society of ethnobiology. Traditional remedies for treatment of commonly encountered disease condition in cattle is documented along with common, scientific name of plant used, family \& method of application. 
International Journal of Science and Research (IJSR)

ISSN (Online): 2319-7064

Index Copernicus Value (2013): 6.14 | Impact Factor (2014): 5.611

\begin{tabular}{|c|c|c|c|c|}
\hline Animal diseases & $\begin{array}{c}\text { Plant used } \\
\text { (Scientific name) }\end{array}$ & Local name & Family & Method of application \\
\hline \multirow{2}{*}{$\begin{array}{c}\text { 1. Foot \& } \\
\text { Mouth disease }\end{array}$} & Acacia arabica & Jali gida & Mimosaceae & \multirow{2}{*}{$\begin{array}{l}\text { Mix bark and root and boil in water with alum } \\
\text { apply on infected area }\end{array}$} \\
\hline & Papaver somniferum & Golagolaki & Papaveraceae & \\
\hline \multirow{3}{*}{ 2. Fever } & Melia azadiracta & Garadabevu & Meliaceae & \multirow{3}{*}{$\begin{array}{l}\text { Mix leaves, grind in water and animal made to } \\
\text { swallow the mixture. }\end{array}$} \\
\hline & Vitex negundo & Huslakki & Verbenacae & \\
\hline & Ricinus communis & Oudala & Euphorbiaceae & \\
\hline $\begin{array}{c}\text { 3. Stomach } \\
\text { diseases /Diarrhea }\end{array}$ & Papaver somniferum & Golagolaki & Papaveraceae & $\begin{array}{l}\text { Grind seeds \& made to swallow the mixture for } \\
\text { 10days. }\end{array}$ \\
\hline \multirow{2}{*}{ 4. Wounds } & Mimosa pudica & Muttidare muni & Mimosaceae & \multirow[t]{2}{*}{ Crush leaves and apply on wounds } \\
\hline & Holoptelia integrifolia & Tapassi & Ulmaceae & \\
\hline 5. Fractures & Vitex negundo & Huslakki & Verbenacae & Grind leaves \& made it to swallow for 7 days. \\
\hline 6. Nose bleeding & Bacopa monnieri & Ondelaga & Scrophulariaceae & Fry leaves with ghee and given orally. \\
\hline
\end{tabular}

\section{Results \& Discussion}

The information already documented covers 06 cattle diseases. A total of 09 plant species were registered against diseases. Verbenacae, Mimosaceae \& Papaveraceae family are species rich in this study. Among the species Vitex negundo, Papaver somniferum, Ocimum basilicum, Ricinus communis are with greatest number of applications. The use of Acacia arabica is as an antiseptic. Holoptelia intergrifolia is recorded for its antibiotic activity. Commonly used routes of drug administration were oral and dermal. Some plants are used to treat more than one disease while some are used as mixtures.

\section{Conclusion}

Due to environmental shrinkage (increasing urbanization, bush fires and loss of native forests), the availability and reliance on the use of plant resources has been significantly reduced. Livestock specialists or vaidyas have a better understanding of plant parts, qualities needed \& methods used in harvesting, processing, storing, preserving the germplasm. If it is poorly executed plant resources may be over exploited which can lead to extinction of certain species. So users should be able to judiciously harvest, preserve and establish botanical gardens by restoring endangered medicinal plants. Traditional \& Ethno veterinary Medicines can contribute to biodiversity conservation by improving the animal health \& restoration of medicinally significant plants.

\section{Reference}

[1] Mathias-Mundy, E. and C.M. McCorkle (1989) Ethnoveterinary medicine:

[2] Nuwanyakpa, M., J. DeVries, C. Ndi and S. Django (1990) Traditional veterinary medicine in Cameroon: A renaissance in an ancient indigenous.

[3] Marcus, S. (1992) A preliminary study on the Anthelminthic properties of Terminalia glaucescens in cattle in the Northwest Province of Cameroon

[4] S.F Uppin(1974) Karnataka sasya sampada 